This article will be published in a revised form in Comparative Studies in Society and History published by Cambridge University Press https://www.cambridge.org/core/journals/comparative-studies-in-society-andhistory/all-issues This version is free to view and download for private research and study only. Not for redistribution, re-sale or use in derivative works. ( $)$

Accepted version downloaded from: http://eprints.soas.ac.uk/23607/

\title{
Transplanted Slavery, Contested Freedom and Vernacularization of Rights in the Reform Era Ottoman Empire
}

\author{
Ceyda Karamursel \\ School of Oriental and African Studies, University of London \\ Department of History
}

In 1861, a Nogai prince named Canpolat, who was expelled from the Caucasus during the ongoing Russo-Caucasian war and settled near Constanza, wrote to the Ottoman officials to complain about the "rebellious behavior" of his five slaves that he brought with him. ${ }^{1}$ Canpolat was one of many Caucasian noblemen who were uprooted from their native lands in the Caucasus during the war and settled in the Ottoman domains. Like many other slaveholding Caucasian noblemen at the time, he brought with him not only his slaves but also his conceptions of slavery, freedom, and law, so much so that he was utterly perplexed when the Ottoman officials responded to his appeal by asking him to pay the pençik tax he owed for his slaves. ${ }^{2}$ Taxes paid on slaves were not known to them in their native lands in Kuban, he objected. Nor was his ownership of the slaves a matter of the sharì'a law that could be litigated or settled at the sharì' $a$ courts. In Canpolat's transplanted perception of law, this process was regulated primarily by

\footnotetext{
${ }^{1}$ Başbakanlık Ottoman Archives (hereafter, BOA), A.MKT.UM 507/61, 1278.R.14 (19 October 1861).

${ }^{2}$ From Persian pandj yak, and equivalent to Arabic khums, pençik tax originally denoted one-fifth share of booty, particularly war captives, set aside for the sovereign. For an overview of its development within Islamic jurisprudence, see A. Zysow, R. Gleave, "Khums," Encyclopaedia of Islam, Second Edition. Edited by: P. Bearman, Th. Bianquis, C.E. Bosworth, E. van Donzel, W.P. Heinrichs. Brill Online, 2016. In the financial and administrative parlance of the late Ottoman state, it signified an ad valorem import tax on slaves. Hakan Erdem, Slavery in the Ottoman Empire and its Demise, 1800-1909 (London: Palgrave Macmillan Limited, 1996), xiii.
} 
This article will be published in a revised form in Comparative Studies in Society and History published by Cambridge University Press https://www.cambridge.org/core/journals/comparative-studies-in-society-andhistory/all-issues This version is free to view and download for private research and study only. Not for redistribution, re-sale or use in derivative works. (C)

Accepted version downloaded from: http://eprints.soas.ac.uk/23607/

customary law, known commonly as 'ädat in the Caucasus, whereas for the Ottoman

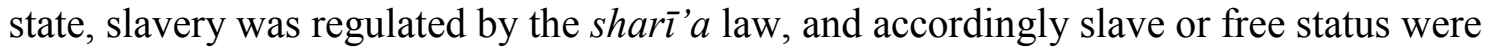
determined at the corresponding courts.

Legal ambiguities that resulted from the mass deportation of the Caucasians into the Ottoman territory were not related to slavery alone. One of earliest and biggest cases of displacement in the global nineteenth century, the Caucasian expulsion necessarily brought about a horde of social, political and, cultural challenges, many of which had their imprint in law. ${ }^{3}$ David Cuthell has noted the social frictions between the incoming refugees with the native tribes in Eastern Anatolia, as well as small-scale brigandage being commonplace from early on in the settlement process. ${ }^{4}$ In Tuna province, where the incoming refugees were found in great numbers, conflicts with the Christian

\footnotetext{
${ }^{3}$ Despite its scale and significance, the Caucasian expulsion remains largely unstudied particularly in terms of its effects on social and legal categories in the Ottoman Empire and Turkish Republic. There are, however, several comprehensive studies on the policy on and the mechanisms of the settlement process. See Mark Pinson, "Demographic Warfare: An Aspect of Ottoman and Russian Policy, 1854-1866," (Ph.D. Dissertation, Harvard University, 1970); David Cameron Cuthell, "The Circassian Sürgün," Ab Imperio, no.3 (2003), in addition to Cuthell's unpublished dissertation "The Muhacirin Komisyonu: An agent in the transformation of Ottoman Anatolia, 1860--1866" (Ph.D. dissertation, Columbia University, 2005); Berat Y1ldı, "Emigrations from the Russian Empire to the Ottoman Empire: An Analysis in the Light of the New Archival Materials," (Master's Thesis, Bilkent University, 2006); Oktay Özel, "Migration and Power Politics: The Settlement of Georgian Immigrants in Turkey (1878-1908)," Middle Eastern Studies, vol.46, no.4 (July, 2010). Other studies look at the Caucasian expulsion as part of a bigger wave of displacement in the late Ottoman Empire. See Kemal H. Karpat, "Ottoman Population Records and the Census of 1881/82-1893," International Journal of Middle East Studies, Vol. 9, No.2 (May, 1978); Alexandre Toumarkine, "Entre empire ottoman et état-nation turc : les immigrés musulmans du caucase et des balkans du milieu du XIXe siècle à nos jours," (Ph.D. Dissertation, Université de Paris IV-Sorbonne, 2000); Dawn Chatty, Displacement and Dispossession in the Modern Middle East (Cambridge: Cambridge University Press, 2010). ${ }^{4}$ Cuthell, "The Circassian Sürgün," 155. BOA also contains numerous files on the conflicts between Caucasian settlers and the native tribes in eastern Anatolia, such as the powerful Afşar tribe.
} 
This article will be published in a revised form in Comparative Studies in Society and History published by Cambridge University Press https://www.cambridge.org/core/journals/comparative-studies-in-society-andhistory/all-issues This version is free to view and download for private research and study only. Not for redistribution, re-sale or use in derivative works. (C)

Accepted version downloaded from: http://eprints.soas.ac.uk/23607/

population were also common. ${ }^{5}$ Fred Burnaby, a British Army intelligence officer on duty in eastern Anatolia shortly before the 1877-78 Russo-Turkish War wrote that the native inhabitants of the region still often complained that the Caucasian refugees had "hazy ideas as to the difference between meum and tuum" and that they were often communally implicated in the cases of brigandage and robbery near their settlements. ${ }^{6}$ In 1880, Edwin Pears, a British barrister living in Constantinople, reported how they had to pay a "Circassian chief" to protect them from being attacked and held to ransom on their way to Nicaea, "as brigands were known to be out in the neighbourhood.", As late as 1890s, Greater Syria was described as a "country [...] infested with Bedouins and Circassian thieves who went unpunished except when the exasperated villagers in sheer desperation resisted."

One of the most vivid descriptions of the tension between the Caucasian refugees' "hazy ideas" and the Ottoman state law came from Krikor Zohrab, who noted that even murder, especially when in the form of retaliation, was not always understood to be a criminal act by the Caucasian refugees. A young, talented criminal defense lawyer by the

\footnotetext{
${ }^{5}$ Cuthell, "The Circassian Sürgün," 160; Milen Petrov, "Everyday Forms of Compliance: Subaltern Commentaries on Ottoman Reform, 1864-1868," Comparative Studies in Society and History, vol. 46, no.4 (Oct., 2004), 749.

${ }^{6}$ Fred Burnaby, On horseback through Asia Minor (London: Sampson Low, Marston, Searle, \& Rivington, 1877), 277. Burnaby also visited Sivas Prison and saw that out of 102 prisoners kept there, the majority were Circassians and Kurds for horse and cattle theft, 285.

${ }^{7}$ Edwin Pears, Forty Years in Constantinople; The Recollections of Sir Edwin Pears, 1873-1915, with 16 Illustrations (London: Herbert Jenkins, 1916), 66-67.

${ }^{8}$ The English Illustrated Magazine, 1891-1892 (London: MacMillan and Co.), 903. Also see Georgi Chochiev and Bekir Koç, "Migrants from the North Caucasus in Eastern Anatolia: Some Notes on Their Settlement and Adaptation (Second Half of the 19th Century-Beginning of the 20th Century) in Journal of Asian History, vol.40, no.1 (2006), 94-95, 97; Ryan Gingeras, Sorrowful Shores: Violence, Ethnicity, and the End of the Ottoman Empire, 1912-1923 (Oxford: Oxford University Press, 2009), 29.
} 
This article will be published in a revised form in Comparative Studies in Society and History published by Cambridge University Press https://www.cambridge.org/core/journals/comparative-studies-in-society-andhistory/all-issues This version is free to view and download for private research and study only. Not for redistribution, re-sale or use in derivative works. ( $)$

Accepted version downloaded from: http://eprints.soas.ac.uk/23607/

1880s and already famous for the work he had undertaken for the Armenian peasants and other unprivileged groups, Zohrab took on the defense of Krandük, a recent refugee from Dagestan who was being charged with first-degree murder. Krandük’s testimony “gave everything away," Zohrab wrote ruefully, and his client's “naivety beyond belief” left no room for the lawyer even to plead not guilty. ${ }^{9}$ The act of murder was a personal incident of retribution that involved Krandük, his childhood friend Nüş and a woman named Ceyran who is implied to have been "appropriated" by the latter in ways not described in the story. The feud that started between the murderer and his victim was consequently carried over to the Ottoman lands, as was their "savage" ways. "Many accepted the Ottoman state's protection as it were the divine order," Zohrab noted, but many others kept with their "nomadic and bellicose habits."10

Starting roughly about mid-nineteenth century, such criminal offences as murder, theft, raiding, pillaging or banditry and the conflicting Caucasian and Ottoman views on them, were addressed and dealt with in accordance with the (trans-)forming criminal law, "which could be anything but taken lightly" as Zohrab described it, and the legal institutions that adjudicated criminal cases. This transformation began with the introduction of the criminal code in 1840 and continued through late 1860 s, generating a hybrid system, in which "crimes against the individual or his/her property were the first

\footnotetext{
${ }^{9}$ Krikor Zohrab, “Ceyran,” in Öyküler (Istanbul: Aras Yayınc1lık, 2001), 140. The story, which was presumably autobiographical, was originally published in Armenian in Hayrenik in 1892.

${ }^{10}$ Ibid., 144.
} 
This article will be published in a revised form in Comparative Studies in Society and History published by Cambridge University Press https://www.cambridge.org/core/journals/comparative-studies-in-society-andhistory/all-issues This version is free to view and download for private research and study only. Not for redistribution, re-sale or use in derivative works. (C)

Accepted version downloaded from: http://eprints.soas.ac.uk/23607/

to be reformed." "By the 1870 s, particularly after the promulgation of the first constitution proper in 1876 and the emergence of the office of public prosecutor "as facilitator of the law" shortly after, the legal procedures for these cases were left with no room for negotiation and called for a definitive decree of punishment. ${ }^{12}$

This was not the case with slavery, partly due to the intrinsically paradoxical status the slaves had in the "era of freedom." ${ }^{\prime 13}$ Being persons and property at the same time, slaves posed a challenge both to the liberal principle of "equality before the law, without rank, distinction, religion, or community," and to the ways in which the categories of the new property regime were translated into legal categories. ${ }^{14}$ The Ottoman state and the Caucasian slaveholders did not necessarily agree on the conditions that sanctioned enslavement, the terms or durations of the slave status or the procedures for manumission, yet those rarely came to contradict one another. In fact, as this article

11 Omri Paz, "Documenting Justice: New Recording Practices and the Establishment of an Activist Criminal Court System in the Ottoman Provinces (1840-late 1860s)," Islamic Law and Society, vol. 21, no.1-2 (2014), 85.

${ }^{12}$ Avi Rubin, Ottoman Nizamiye Courts: Law and Modernity (New York: Palgrave Macmillan, 2011), 136; Kent F. Schull, Prisons in the Late Ottoman Empire: Microcosms of Modernity (Edinburgh: Edinburgh University Press, 2014), 22-25.

${ }^{13}$ There is a large literature on this particular paradox and how it shaped social and legal categories and in an indirect way, citizenship in the nineteenth century Atlantic world. See especially Thomas C. Holt, The Problem of Freedom: Race, Labor, and Politics in Jamaica and Britain, 1832-1938 (Baltimore: The Johns Hopkins University Press, 1992); Frederick Cooper, Thomas C. Holt, Rebecca J. Scott, Beyond Slavery: Explorations of Race, Labor, and Citizenship in Postemancipation Societies (Chapel Hill: The University of North Carolina Press, 2000); Rebecca J. Scott, Degrees of Freedom: Louisiana and Cuba after Slavery (Cambridge, MA: Harvard University Press, 2005); Richard Follett, Eric Foner, and Walter Johnson, Slavery's Ghost: The Problem of Freedom in the Age of Emancipation (Baltimore: Johns Hopkins University Press, 2011).

${ }^{14}$ Yücel Terzibaşoğlu provides an excellent analysis of this particular issue from the viewpoint of land ownership and agrarian regimes. Yücel Terzibaşoğlu, "The Ottoman Agrarian Question and the Making of Property and Crime in the Nineteenth Century," in Ottoman Rural Societies and Economies, ed. Elias Kolovos (Rethymno: Crete University Press, 2015), 324-325. 
This article will be published in a revised form in Comparative Studies in Society and History published by Cambridge University Press https://www.cambridge.org/core/journals/comparative-studies-in-society-andhistory/all-issues This version is free to view and download for private research and study only. Not for redistribution, re-sale or use in derivative works. (C)

Accepted version downloaded from: http://eprints.soas.ac.uk/23607/

aims to show, they often worked in support of each other, delineating a system of slavery which could be defined neither as a Caucasian life-term serfdom or chattel type of slavery nor exactly an Islamic one, but a combination of the two, whose bind became virtually impossible to break out of for the enslaved, as well as the reformers that aimed for general abolition in the second half of the nineteenth and early decades of the twentieth centuries. $^{15}$

What did not pose a problem for the Ottoman state and the Caucasian slaveholders' perception of law, however, was complicated by another legal development that was taking shape from early nineteenth century on. In that, the global spread of the anti-slavery politics, laws and regulations, the first full articulation of which took place in 1857 in the Ottoman Empire, added yet another layer of complexity to the post-Caucasian expulsion Ottoman Empire and how slavery, freedom and what came to be named citizenship rights were understood and handled there. These global developments provided the incoming enslaved refugees with the incentive to question their status as slaves and claim freedom, which they deemed to be their right, whatever that may have meant in specific contexts. In the subsequent decades, they challenged the very legitimacy of the $\operatorname{shar}_{\bar{l}}$ ' courts as justice administering institutions and increasingly

\footnotetext{
${ }^{15}$ Different aspects of this particular point have been raised by the historians of Ottoman and Middle Eastern slavery. See especially Erdem, Slavery in the Ottoman Empire, 147-151; Ehud R. Toledano, Slavery and Abolition in the Ottoman Middle East (Seattle: University of Washington Press, 1998), 96-99.
} 
This article will be published in a revised form in Comparative Studies in Society and History published by Cambridge University Press https://www.cambridge.org/core/journals/comparative-studies-in-society-andhistory/all-issues This version is free to view and download for private research and study only. Not for redistribution, re-sale or use in derivative works. ( $)$

Accepted version downloaded from: http://eprints.soas.ac.uk/23607/

placed more faith on such overtly secular institutions as the Ministry of Justice and the Parliament, than on the religious ones. ${ }^{16}$

This article seeks to explore the jurisdictional conflicts that emerged at the juncture of the transplanted legalities that followed the Caucasian expulsion in the $1850 \mathrm{~s}$ and 60s, the promulgation of the proto-constitution known as the Ottoman Reform Edict of 1856, and the internationally enforced trade ban in African slaves in 1857. Starting with the Caucasian expulsion, it traces how legal practices were carried over with Caucasian refugees to the Ottoman domains and how the judicial management of slaveryrelated conflicts determined not only the limits of slavery, but also how such liberal "fictions" as freedom or equality before the law were vernacularized by the local agents in the Ottoman Empire. Navigating within a set of what was labeled as hürriyet davalarl (freedom suits), it looks at how enslaved refugees built their claims in relation to different legal terrains, problems and concepts, ultimately arguing that while Caucasian-Ottoman slavery was economically marginal, it posed serious challenges to the new political order the Ottomans aspired to establish and the abolition that never came continued to bend the categories of ethnicity, race and gender, contributing to the "violent turn" of events in the subsequent decades.

\section{The Caucasian Expulsion and Transplanted Legalities}

\footnotetext{
${ }^{16}$ Ceyda Karamursel, "The Uncertainties of Freedom: The Second Constitutional Era and the End of Slavery in the Late Ottoman Empire," Journal of Women's History, volume 28, no. 3 (2016), 145.
} 
This article will be published in a revised form in Comparative Studies in Society and History published by Cambridge University Press https://www.cambridge.org/core/journals/comparative-studies-in-society-andhistory/all-issues This version is free to view and download for private research and study only. Not for redistribution, re-sale or use in derivative works. ( $)$

Accepted version downloaded from: http://eprints.soas.ac.uk/23607/

Krikor Zohrab was not the first to give an account of the chaotic air among the Caucasian refugees, although he may have been the only one to depict it in a courtroom. Not only the hardships, such as the diseases and destitution that the refugees encountered during their passage and settlement, but also a good amount of information from the profuseness of the languages they spoke to the strangeness of their customs appeared in journals and newspapers worldwide. Especially the British public, whose interest was shaped by strong anti-Russian sentiments, read a great deal about "the brave and hardy" people of the Caucasus, "finished by exile, fever, famine ague, and, far worse than all, cruelty."17

Besides the settlement and integration problems, difficulties arose in relation to the Ottoman government's policies that aimed to settle the refugees in strategic places, such as the border regions. The Ottoman government deemed it advantageous to populate its margins with the incoming Caucasians not only on the account of an outside threat (as was the case in Tuna province, in relation to Russia, for instance) but also for managing the native populations of the empire. ${ }^{18}$ The highly fractured nature of the refugees (and the hostilities and feuds that they brought with them) nullified any possibility of forming a unified Caucasian community. ${ }^{19}$ As the British consul in Soukoum-Kalé, Dickson,

\footnotetext{
17 "The Circassian Exodus," The Quiver, June 1864, 214; "National Extinction of the Circassian People," The London Journal, July 23, 1864, 61; For the connection of this coverage to the Crimean War, see Candan Badem, The Ottoman Crimean War (1853-1856) (Leiden: Brill, 2010). ${ }^{18}$ Janet Klein, The Margins of Empire: Kurdish Militias in the Ottoman Tribal Zone (Stanford: Stanford University Press, 2011), 165-166; Cuthell, "The Muhacirin Komisyonu," 175-176; Gingeras, Sorrowful Shores, 26. For deployment of the incoming refugees as "demographic weapon" see Pinson, "Demographic Warfare;" Eugene Rogan, Frontiers of the State in the Late Ottoman Empire: Transjordan, 1850-1921 (Cambridge: Cambridge University Press, 2002), 72. ${ }^{19}$ See BOA, A.MKT.MHM 168/33, 1276.Ra.23 (20 October 1859) for an official correspondence which points out to the governors of Silistra and Varna that a Bzhedug tribe consisting of 44
} 
This article will be published in a revised form in Comparative Studies in Society and History published by Cambridge University Press https://www.cambridge.org/core/journals/comparative-studies-in-society-andhistory/all-issues This version is free to view and download for private research and study only. Not for redistribution, re-sale or use in derivative works. (C)

Accepted version downloaded from: http://eprints.soas.ac.uk/23607/

reported to Earl Russell in February 1864, "the absence of all political cohesion between

the northern tribes, or such remnants thereof, and those inhabiting other parts of the

Caucasus, and, indeed, the almost utter impossibility of bringing about such a

consummation" was one of the major misfortunes that fell on the people of the Caucasus.

"Each and all cannot be made to forget their blood feuds," Dickson noted, "still less to

unite in a common cause..."20 However, formidable addition to the empire's

"Mahomedan population," they proved useful in destabilizing existing structures of

power and networks of influence, particularly the early groups of refugees who were

reportedly armed. ${ }^{21}$ This situation, which produced ample amount of tension between the

refugees and local populations, caused frequent clashes across the Ottoman lands.

In some instances these hostilities and clashes were circumstantial, which were

forced upon the refugees, as mentioned above, by the difficult conditions of refugee life

households and 365 individuals was not to be mixed with the Tatars when settled in Dobruca (Dobrich). Also see A.MKT.UM 400/96, 1276.Ş.24 (17 March 1860) and A.MKT.UM 405/51, 1276.L.24 (15 May 1960) for orders to combine and separate groups along declared tribal affiliations. Also see David Cuthell, "The Muhacirin Komisyonu," 172. Cuthell specifies the Russo-Caucasian war under Shamyl's leadership as the last [and possibly the only] "meaningful organized resistance" among the Caucasians. Cuthell, "The Circassian Sürgün," 145. However, there was also a simultaneous anxiety about Caucasian immigrants becoming a unified group. See for instance BOA, A.MKT 17/14 1260.N.25 (8 October 1844) for a note written by the Grand Vizier to the governor of Filibe (Plovdiv), cautioning him to keep a close eye on a Circassian prince named Safer, not to let him travel outside of Edirne or communicate with other Circassians.

${ }^{20}$ Note no.2, Consul Dickson to Earl Russell in Papers Respecting the Settlement of the Circassian Emigrants in Turkey: Presented to the House of Commons by Command of Her Majesty, in pursuance of their Address dated June 6, 1864 (London: Harrison \& Sons, 1864).

${ }^{21}$ Cuthell, "The Circassian Sürgün," 150. Also see B. Philpot, The Times, Letters to the Editor, June 17, 1864, p.7 and a note sent to the governor of Vidin in 1861, cautioning him against the armed Crimean, Nogai and Circassian settlers. BOA, A.MKT.MHM 238/12, 1278.Ca.28 (1 December 1861). 
This article will be published in a revised form in Comparative Studies in Society and History published by Cambridge University Press https://www.cambridge.org/core/journals/comparative-studies-in-society-andhistory/all-issues This version is free to view and download for private research and study only. Not for redistribution, re-sale or use in derivative works. (C)

Accepted version downloaded from: http://eprints.soas.ac.uk/23607/

or on the poor peasant populations trying to make ends meet. ${ }^{22}$ In many cases however,

the documents on these social explosions made specific references to Caucasian

customary or ancient laws (kanun-i kadim). Analogous, in many respects, to Chinggisid

yasa or Timurid töre, these legal codes were made up of an "evolving body of individual

decrees, regulations, and practices that had been instituted or sanctioned by [the

sovereign] ... a kind of unwritten 'constitution'."23 While they varied significantly from

one tribal organization to another, particularly in regards to the ways and degrees they

were affected by the sharī'a law, these legal practices were strictly observed in settling

criminal offences and civil matters, including the act of enslavement, slavery and slave

trade in the Caucasus. In that, customary law was not any law-like social behavior that

remained outside of or opposed the state law, nor should it be presumed, as Mitra Sharafi

cautions the scholars of legal pluralism, to be less coercive than state law. ${ }^{24}$

\footnotetext{
${ }^{22}$ Reşat Kasaba, A Moveable Empire: Ottoman nomads, migrants, and refugees (Seattle: University of Washington Press, 2009), 117-118.

${ }^{23}$ Guy Burak, The Second Formation of Islamic Law: The Hanafi School in the Early Modern Ottoman Empire (New York: Cambridge University Press, 2015), 215.

${ }^{24}$ Lauren Benton and Richard J. Ross, "Introduction," Legal Pluralism and Empires, 1500-1850, eds. Lauren Benton and Richard J. Ross (New York: NYU Press, 2013), 4-5; Mitra Sharafi, "Justice in Many Rooms Since Galanter: De-romanticizing Legal Pluralism through the Cultural Defense," Law and Contemporary Problems, vol. 71 (2008), 139. There is a large body of literature on pluralistic legal orders in the Ottoman Empire, which have been classically understood, as exemplified in a recent article by Karen Barkey, as the coexistence of and interaction between different religious legal bodies. Karen Barkey, "Aspects of Legal Pluralism in the Ottoman Empire," in Legal Pluralism and Empires, 1500-1850. There is a growing effort by the Ottoman and Middle Eastern legal historians to include indigenous forms of governance and legal practices in the study of the Ottoman Middle East. For two excellent examples, see Nora Barakat, "Marginal Actors? The Role of Bedouin in the Ottoman Administration of Animals as Property in the District of Salt, 1870-1912," and Yuval Ben-Bassat, "Bedouin Petitions from Late Ottoman Palestine: Evaluating the Effects of Sedentarization," both in Journal of the Economic and Social History of the Orient, vol. 58, no. 1-2. For a comprehensive discussion on the necessity of complicating the state law within legal pluralism debate, see Ido Shahar, "State, Society and the Relations Between Them: Implications for the Study of Legal Pluralism," Theoretical Inquiries in Law, vol. 9 (2008); Specifically for the Caucasus, see Rebecca Gould,
} 
This article will be published in a revised form in Comparative Studies in Society and History published by Cambridge University Press https://www.cambridge.org/core/journals/comparative-studies-in-society-andhistory/all-issues This version is free to view and download for private research and study only. Not for redistribution, re-sale or use in derivative works. (C)

Accepted version downloaded from: http://eprints.soas.ac.uk/23607/

Prior to coming to the Ottoman Empire, slaveholding Caucasians like Canpolat either inherited their slaves or obtained them through what Georges Charachidze described as a "complex and diversified cycle of exchanges that combined agricultural production, commerce and pillage." 25 Practices such as raiding, kidnapping, prolonged blood feuds and blood money, all parts of this cycle, were prevalent even in the most distinctively Muslim parts of the Caucasus, despite that they were often at odds with Islamic jurisprudence in fundamental ways. In contrast to shar $\bar{\imath}$ ' , for instance, 'ādat did not differentiate personal and collective responsibility for a crime nor it separated accidental offences from the deliberate ones. Sharì' $a$, on the other hand, recognized the legitimacy of blood feuds but it prohibited taking revenge on collective basis. ${ }^{26}$ Despite these discrepancies however, even Dagestanis, who had a long history and tradition of muridism and claimed Muslim leadership against Russia during the war, had "from time almost immemorial, been engaged in a deadly struggle for mutual destruction," ordinarily raided their neighbors and converted their "kanlys and needy debtors into slaves." 27 The long-lasting Russo-Caucasian war sharpened the existing enmities between different

"Ijtihād against Madhhab: Legal Hybridity and the Meanings of Modernity in Early Modern Daghestan," Comparative Studies in Society and History, vol.57, no.1 (2015).

${ }^{25}$ Georges Charachidze, "Types de Vendetta au Causase," in La Vengeance. Etudes d'ethnologie, d'histoire et de philosophie. ed. Raymond Verdier (Paris: Editions Cujas, 1980), 89. For a more recent and comprehensive discussion on slave-producing cultural practices such as bridekidnapping or amanat, see Bruce Grant, The Captive and the Gift: Cultural Histories of Sovereignty in Russia and the Caucasus (Ithaca: Cornell University Press, 2009).

${ }^{26}$ Anna Zelkina, In Quest for God and Freedom: Sufi Responses to the Russian Advance in the North Caucasus (New York: NYU Press, 2000), 40-41.

${ }^{27}$ For a contemporary account, see Ivan Golovin, The Caucasus (London: Trübner \& Co., 1854), 165; Elena Inozemtseva, "On the History of Slave-Trade in Dagestan," in Iran \& the Caucasus, vol.10, no.2 (2006), 186. Kanly, which literally means bloody or blood stained in Turkish, is a term used to describe those who killed a person and thus owed either his life or a corresponding blood money to the victim's relatives; Liubov Kurtynova-D'Herlugnan, The Tsar's Abolitionists: The Slave Trade in the Caucasus and Its Suppression (Leiden: Brill, 2010), 14. 
This article will be published in a revised form in Comparative Studies in Society and History published by Cambridge University Press https://www.cambridge.org/core/journals/comparative-studies-in-society-andhistory/all-issues This version is free to view and download for private research and study only. Not for redistribution, re-sale or use in derivative works. (C)

Accepted version downloaded from: http://eprints.soas.ac.uk/23607/

tribal groups, formed new alliances and disbanded old ones in the region. It also rendered slaves, whose trade was controlled and organized primarily by the Caucasian nobility and run by Turkish or Tatar intermediaries, the primary commodity to finance the war, especially during its final decades. ${ }^{28}$

Besides the hostilities and clashes that took place between the refugees and native populations, or among different Caucasian tribal groups with ongoing feuds carried over to the Ottoman lands, what posed a major concern for the Ottoman government in regards to the incoming refugees had to do with the disputes and conflicts within the tribal organizations themselves. The refugees moved to the Ottoman Empire organized as tribes and clans, although that did not necessarily mean that they saw themselves as homogenous units. The Caucasian social order was peculiar in that, as Paul Manning describes it, they 'contained 'feudal' distinctions of hereditary caste but situated within a generally egalitarian 'acephalous' segmentary political structure," which could be interpreted as highly hierarchical (thus ripe for indirect rule, with the co-optation of the nobility) or "a miniature Liberal revolution," depending on who looked at them. ${ }^{29}$ The Adyghe, for instance, had four castes composed of the princes, nobles, freemen, and serfs/slaves. ${ }^{30}$ One slave petition from 1872 (of unidentified tribal affiliation) noted that even the slave class was stratified and consisted of two types of slaves. The abd-l memluk was responsible for giving half of their crop to the prince every year and could also be

\footnotetext{
${ }^{28}$ Inozemtseva, "On the History of Slave-Trade in Dagestan," 185; İbrahim Köremezli, "The Place of the Ottoman Empire in the Russo-Circassian War (1830-1864)," (Master's thesis, Bilkent University, 2004), 41-42.

${ }^{29}$ Paul Manning, "Just Like England: On the Liberal Institutions of the Circassians," Comparative Studies in Society and History, vol.51, no.3 (2009), 591.

${ }^{30}$ Köremezli, "The Place of the Ottoman Empire," 7.
} 
This article will be published in a revised form in Comparative Studies in Society and History published by Cambridge University Press https://www.cambridge.org/core/journals/comparative-studies-in-society-andhistory/all-issues This version is free to view and download for private research and study only. Not for redistribution, re-sale or use in derivative works. (C)

Accepted version downloaded from: http://eprints.soas.ac.uk/23607/

sold. The abd-ı hür, on the other hand, also had the obligation of the yearly payment but could not be sold. ${ }^{31}$ A retrospective and nation or ethnicity-focused view of these groups may inevitably yield an image of them as cohesive and integral groups (in the face of Russian empire's encroachment that they ran away from or the Ottoman Empire, which tried hard to absorb them) but from early on with their arrival, there were clear indications that this was not the case. In most instances, internal, minor disputes or offences that happened within the group were kept to the group, partially due to the fact that the refugees had to work against a language barrier, as they did not speak Turkish. ${ }^{32}$ Aside from those, many of the conflicts that ended up with the government authorities or legal institutions such as the local sharī'a courts, had to do with the practice of slavery and the incoming refugees' slave status.

As one slave petition submitted to the office of the Grand Vizier in 1859 made it clear, the major cause for the slaves' discontent was almost always the slaveholding elites (who, in this example, belonged to the Kabarda/Kabarta tribe) resorting to their "old customs" of selling the children, particularly the daughters, of their slaves. ${ }^{33}$ This particular complaint appeared in slave petitions recurrently, even during the early phases of the expulsion when most of the incoming slaveholding nobility was relatively wealthy and were not in immediate need to sell their slaves. ${ }^{34}$ In another case from 1861 , for

\footnotetext{
${ }^{31}$ BOA, ŞD 2872/30, 1289.Ra.7 (15 May 1872).

${ }^{32}$ See, for instance, BOA, MVL 620/84, 1278.B.20 (21 January 1862), for a case of murder that occurred between two brothers, recent immigrant-refugees from the Caucasus, whose interrogation was conducted by the help of an interpreter. Also see Ömer Karakaş, "19. Yüzy1lda Anadolu' da Çerkes Göçmenlerinin İskânlari Sirasinda Karşilaştiklari Sorunlar: Uzunyayla Örneği," Karadeniz Araştırmaları, no. 36 (K1ş 2013), 88-89.

${ }^{33}$ BOA, A.MKT.MHM 176/37, 1276.B.09 (1 February 1860).

${ }^{34}$ Cuthell, "The Circassian Sürgün," 146.
} 
This article will be published in a revised form in Comparative Studies in Society and History published by Cambridge University Press https://www.cambridge.org/core/journals/comparative-studies-in-society-andhistory/all-issues This version is free to view and download for private research and study only. Not for redistribution, re-sale or use in derivative works. (C)

Accepted version downloaded from: http://eprints.soas.ac.uk/23607/

instance, two enslaved men named Mehmed and Mustafa filed a petition, again with the office the Grand Vizier, to complain about their owners, who were, in accordance with the old customs, "in the mind of selling" the formers' daughters. The slave owners had declared that they were allowed to do so by the orders of the Sultan, even though the young girls were engaged and soon to be married. ${ }^{35}$ Mehmed and Mustafa stated that if such an order indeed existed, they were ready to comply with the Ottoman sovereign's wishes, for they too were the subjects of the Sultan and moreover, "all praise be to God," Muslims. If not however, they asked to be released from what they deemed illegitimate bonds of their so-called owners. ${ }^{36}$ Later on, as the legal suits and procedures became more widespread and the legal language of slavery and freedom became more established, the parties debated over the contested notion of dominium (kanun-i malikiye), which the slave owners rooted again in the "ancient law," whereas the slaves asked for a new definition, both of slavery and ownership in general. ${ }^{37}$

To be added to the disputes on the descriptions and limitations of slave ownership are the cases of apparent "blunders" by the enslaved refugees themselves. Slave flights,

${ }^{35}$ BOA, A.MKT.DV 181/59, 1277.B.19 (31 January 1861).

${ }^{36}$ Ibid.

${ }^{37}$ BOA, ŞD 2872/30, 1289.Ra.7 (15 May 1872). Private ownership and property rights particularly of land, as opposed to usufruct rights, were also a nineteenth century development that culminated in the Ottoman Land Reform of 1858. Alan Mikhail, "Unleashing the Beast: Animals, Energy, and the Economy of Labor in Ottoman Egypt," The American Historical Review (2013) 118 (2), 341. For a comprehensive treatment of property ownership in Egypt, also see Kenneth M. Cuno, The Pasha's Peasants: Land, Society, and Economy in Lower Egypt, 1740-1858 (Cambridge: Cambridge University Press, 1992). Specifically on the Ottoman Land Code of 1858, see Huri Islamoglu, "Property as a Contested Domain: A Reevaluation of the Ottoman Land Code odf 1858," in New Perspectives on Property and Land in the Middle East, eds. Roger Owen and Martin P. Bunton (Cambridge, MA: Harvard University Press, 2011).

The enslaved refugees' efforts to push for a new definition of ownership should be viewed within this larger framework of changing notions of property ownership. 
This article will be published in a revised form in Comparative Studies in Society and History published by Cambridge University Press https://www.cambridge.org/core/journals/comparative-studies-in-society-andhistory/all-issues This version is free to view and download for private research and study only. Not for redistribution, re-sale or use in derivative works. (C)

Accepted version downloaded from: http://eprints.soas.ac.uk/23607/

for one, were instances in which the customary law was speedily transported into the Ottoman sharì' $a$ and public law, by pushing the slaveholder to appeal to and demand from the legal and governmental institutions to set its coercive measures against their slaves' "rebellious" behavior. ${ }^{38}$ Such was the case with Ömer, a slave owner from Şibu (possibly, Şabsu or Shapsug) tribe, for instance. When two male and three female slaves of his ran away to Rhodes island in 1860 , he petitioned the office of the Grand Vizier, requesting the recovery of the runaway slaves. The Grand Vizierate, for its turn, found the case to be the matter of the shari' $a$ law and ordered that it be heard at the corresponding court and dealt with in accordance with the legal decision. ${ }^{39}$ Many of the major conflicts reported by the slaves and slave owners directly resulted from an ambiguous notion of ownership rights over people that referred to both customary and $\operatorname{sharì'}^{\prime} a$ law at once. This situation rendered, in a nutshell, the implementation of these laws the very source of the problem itself.

The individual sale of family members and the breaking up of families produced violent resistance against the slave owners and caused closer appeal to the Ottoman government on the slaves' side. To exemplify, cashing in on his "transplanted" privileges, a slaveholder named Kaspolat attempted to sell five of his slaves, Makval (or

\footnotetext{
${ }^{38}$ Ehud Toledano insightfully explored how running away or absconding were strategized and used by the enslaved men and women themselves. See Ehud R. Toledano, As if Silent and Absent: Bonds of Enslavement in the Islamic Middle East (New Haven: Yale University Press, 2007), 60107. Here, I am building on Toledano's observations but more concerned how slave flights were translated into legal categories vis-à-vis citizenship rights. As Toledano also argues, most of Caucasian enslaved refugees were considered serfs in their native lands and became slaves only after they entered the Ottoman Empire, because that was the only legal category available for them. Toledano, As if Silent and Absent, 95. This, however, was not an automatic process but took shape as the enslaved and slave holding refugees and the Ottoman state interacted in different capacities in the aftermath of the Caucasian expulsion.

${ }^{39}$ BOA, A.MKT.MHM, 176/75, 1276.B.11 (3 February 1860).
} 
This article will be published in a revised form in Comparative Studies in Society and History published by Cambridge University Press https://www.cambridge.org/core/journals/comparative-studies-in-society-andhistory/all-issues This version is free to view and download for private research and study only. Not for redistribution, re-sale or use in derivative works. (C)

Accepted version downloaded from: http://eprints.soas.ac.uk/23607/

Markoval, 36 years old), his wife (35 years old) and their children (whose age ranged

between 14 and 4 years), but met fierce resistance from the family, whose appeals stated that they would rather "bring themselves to ruin and perish" than seeing their family be broken, and themselves be removed from the remainder of their extended family and relatives. ${ }^{40}$ Their appeal found support from the district governor of Yanbolu, who stated that selling those over thirty years of age and those who had children would be violating the notion of the family, and suggested that the sale should be halted. ${ }^{41}$ Through a decision by the Supreme Council of Judicial Ordinances (Meclis- $i$ Vâlâ-yı AhkâmAdliye), two legal systems and privileges came face to face to determine (or at least, emphasize) the age limits as well as its legal implications within the practice of slavery. ${ }^{42}$

In many of the cases of conflict and complaints, the slave owners continued to clutch to the notion of an "adat-ı kadime" that originated from their native lands referred to as "vatan-l asliye" or simply as Kuban like the Nogai prince Canpolat did in his letter that opens this article. The enslaved, on the other hand, followed the legal developments more closely, achieved some degree of knowledge and sense as to what their rights were,

\footnotetext{
${ }^{40}$ BOA, MVL 991/62, 1281.M.13 (18 June 1864). Toledano has argued that the established Caucasian customs were strongly in favor of maintaining the unity of slave families and it was the "hardships of emigration [which] eroded the old and established customs." Ehud Toledano, The Ottoman Slave Trade and its Suppression: 1840-1890 (Princeton: Princeton University Press, 1982), 160; Toledano, As if Silent and Absent, 98. While the difficulties encountered during the expulsion and settlement process shifted the ethical boundaries of the slave owners and traders, the petitions written by the enslaved themselves indicate that it was already the prerogative of the slave-holding elite to sell their slaves at will. For a comprehensive discussion on this particular point, see Kurtynova-D'Herlugnan, The Tsar's Abolitionists, 1-36.

${ }^{41}$ The sale of the family was reportedly annulled, as an official notice sent by the Supreme Council to the Grand Vizier clarified. BOA, MVL 996/26, 1281.S.21 (26 July 1864).

${ }^{42}$ See BOA, MVL 991/39, 1280.Z.29 (5 June 1864), for a brief note on the extension of the age limit to all Caucasian tribes. Written by the Supreme Council to the governor of Varna, the note stated that the condition (mesağ) of the permissibility or lawfulness of the sale of the tribe members relied upon the age limitations determined by the Supreme Council earlier.
} 
This article will be published in a revised form in Comparative Studies in Society and History published by Cambridge University Press https://www.cambridge.org/core/journals/comparative-studies-in-society-andhistory/all-issues This version is free to view and download for private research and study only. Not for redistribution, re-sale or use in derivative works. (C)

Accepted version downloaded from: http://eprints.soas.ac.uk/23607/

and acted, at times in an organized manner, to obtain or at least claim them. Starting early on with the emigration process, the enslaved refugees were highly vocal in demanding change to their status, at times acting "rebelliously," and potentially, mutinously. In the aftermath of their expulsion from Russia, where, as they themselves put it, they "left all that they owned, except for their poverty," the impoverished refugees were less likely to go into bloody conflicts within their community. Nevertheless, the instances of violent encounters did exist and both the possibility and fear of its frequency remained real. ${ }^{43}$ Ehud Toledano depicts a case of violent clash between slave owners and their slaves as follows:

On 9 September 1866 the governor of the Vilâyet of Edirne reported to the Grand Vezir that violent clashes had erupted in the village of Mandira between Circassian slave holders and their slaves. The issue was the slaves' status. A few policemen were sent to stop the fighting, but they were barred from entering the village. When the authorities learned about this, they immediately dispatched more policemen under the command of a binbaşı (equivalent rank of a major). This time the police managed to control the situation and put an end to the skirmish, but the dispute which had caused it still remained unresolved. The slaves demanded to be freed, and the slave holders refused to manumit them. The governor reported that he had sent to the village one of his staff officers to mediate between the factions. He was concerned, however, that with 400 households of immigrants - all armed — fighting could be resumed at any time. Therefore, the Vâli suggested that the villagers be disarmed, and he asked the

\footnotetext{
${ }^{43}$ BOA, A.DVN 156/50, 1277.Ra.03 (19 September 1860). The armed clashes between the slave owning classes and slaves did occur especially in the aftermath of the 1908 revolution, when the Caucasian slaves claimed full citizenship in the new constitutional order and when the government did give both the slaves and slave owners confusing messages by drafting enslaved men for the army. Gûâze, sene 1, numara 9, 19 Mayıs 1327 (1 June 1911), 5.
} 
This article will be published in a revised form in Comparative Studies in Society and History published by Cambridge University Press https://www.cambridge.org/core/journals/comparative-studies-in-society-andhistory/all-issues This version is free to view and download for private research and study only. Not for redistribution, re-sale or use in derivative works. ( $)$

Accepted version downloaded from: http://eprints.soas.ac.uk/23607/

Grand Vezir to authorize this move. ${ }^{44}$

The Ottoman government was not there solely to appease these tensions, however, nor to act as a judge to bring a mutual solution for the parties involved. It was there also to code the slaveholding and enslaved refugees' behavior and place them in the "grid of law" that it was weaving. Such was the case with Listan, Yunus, and Zekeriya, three of Makhar Ahmed's slaves, who took up rifles and shot at the latter's house one night. In their interrogation, they said that they did so not with the purpose of killing him, but rather to frighten him, so that he would forgo the cruel treatment and torture he applied to his slaves. ${ }^{45}$ Just like slave flights, these offences sped up the process of legal assimilation of the enslaved refugees and often highlighted if not imposed a uniform meaning of their slave status. In the case of Listan, Yunus, and Zekeriya, for instance, their offence was brought to the local and eventually higher court of Supreme Council, determined to be a criminal offence punishable in accordance with the article 179 of the Ottoman Criminal Law that called for imprisonment for the duration of one week to six months. But since these three slaves (whose enslaved status was established with the very first question in their interrogation) committed the offence against their masters (efendi), their bold attempt was found to be an aggravating factor, and their sentence was determined to be imprisonment for the duration of a full year. Thus, by coding the enslaved refugees' act against their owners as such, the Ottoman government, and its law

\footnotetext{
${ }^{44}$ Toledano, The Ottoman Slave Trade and its Suppression, 162-163.

${ }^{45}$ BOA, MVL 698/20, 1281.L.13 (11 March 1865). BOA, A.MKT.UM 507/61.
} 
This article will be published in a revised form in Comparative Studies in Society and History published by Cambridge University Press https://www.cambridge.org/core/journals/comparative-studies-in-society-andhistory/all-issues This version is free to view and download for private research and study only. Not for redistribution, re-sale or use in derivative works. (C)

Accepted version downloaded from: http://eprints.soas.ac.uk/23607/

administering institution helped define these relationships as something above the ordinary and essentially unequal.

While, judging by the age composition, many of the slaves who were recorded in the settlement registers were inherited and could be claimed ancestrally, ${ }^{46}$ the ancient law, "adat-ı kadime" was evoked not solely or necessarily to refer to ancestral rights to own slaves, whose enslavement took place during the tribes' long-gone days in the Caucasus mountains. In fact, "adat-ı kadime" did not only refer to the ownership of slaves, but also the means of enslavement, in accordance with these customs. In many instances, these were crude expressions of power, when Caucasian nobility claimed the rights to the labor or sexual services (istihdam and istifraş, respectively) of the destitute members of their groups. In one such case, a Caucasian man from Hatuqwai tribe named Dingozi and his seven friends petitioned the office of the Grand Vizier in 1859, and complained about a man named Hapuzi (or, Hapuji) for employing them forcefully and without payment. The petitioners asked the Grand Vizier to look into the matter or at

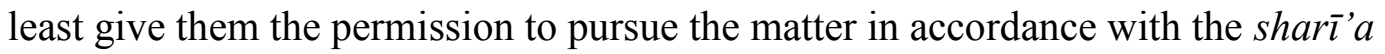
formulations. ${ }^{47}$ Another brief notice from 1865 reported on the enslavement of Receb and

\footnotetext{
${ }^{46}$ For examples of these settlement registers, see BOA, A.DVN 147/43, 1276.R.4 (31 October 1859); A.DVN 147/27 1276.R.4 (31 October 1859); DH.MHC 1/60, 1277 (1860-61); Taksim Atatürk Kütüphanesi, Belediye Yazmaları, BEL_Yz_B.000059, 1294 (1877-78). Broken down into families of different sizes, each entry in the register began with a brief visual description (particularly of height and the shape and color of the beard), name and age of the head of the family followed by information on the remainder of the family members, starting with the wives and ending with the slaves that the family owned.

${ }^{47}$ BOA, A.DVN 146/11, 1276.S.14 (12 September 1859).
} 
This article will be published in a revised form in Comparative Studies in Society and History published by Cambridge University Press https://www.cambridge.org/core/journals/comparative-studies-in-society-andhistory/all-issues This version is free to view and download for private research and study only. Not for redistribution, re-sale or use in derivative works. ( $)$

Accepted version downloaded from: http://eprints.soas.ac.uk/23607/

Bata Agurli by a man named Koç Çoseb. ${ }^{48}$ As it would be reported many years later, in addition to those who came to the Ottoman Empire as slaves, many were enslaved en route to the Ottoman lands due to the harsh conditions of the journey that cost the lives of 200 to 300 people every day. ${ }^{49}$ Especially in the aftermath of the constitutional revolution in 1908, during which slave claims to freedom virtually exploded, many stories of "unjust enslavement" during the Caucasian expulsion came to the fore, to undo slaveholders' claims to ancestral slave ownership. ${ }^{50}$

Ehud Toledano has argued that it was the penalties not being strong enough for kidnapping and enslavement that allowed the traffic to go on unhindered throughout the remainder of the nineteenth and early twentieth centuries. Yet, this argument readily attributes universality to the newly adopted Ottoman criminal code, and the justice it promised. ${ }^{51}$ The penal code was not there to be simply and universally adopted by everyone, including the incoming Caucasian refugees, whose justice system worked differently than both the sharī'a law that sought to maintain status quo above all, or the penal code that aimed to reach a universal justice at all costs. It was there to be negotiated, by those who were also negotiating their participation and inclusion to the Ottoman Empire. The slaveholding and enslaved refugees grasped it from different ends

\footnotetext{
${ }^{48}$ BOA, A.MKT.MHM 332/32, 1281.Z.21 (17 May 1865). Also see MVL 529/110, 1283.Z.29 (4 May 1867), in which 26 individuals were enslaved, reportedly with the simple promise of protection.

${ }^{49}$ Toledano, The Ottoman Slave Trade and its Suppression, 150-151.

${ }^{50}$ For example, see DH.MKT 2891/97, 1327.B.17 (4 August 1909). Also see Karamursel, "The Uncertainties of Freedom," 146.

${ }^{51}$ Toledano, The Ottoman Slave Trade and its Suppression, 168; Toledano, Slavery and Abolition, 33.
} 
This article will be published in a revised form in Comparative Studies in Society and History published by Cambridge University Press https://www.cambridge.org/core/journals/comparative-studies-in-society-andhistory/all-issues This version is free to view and download for private research and study only. Not for redistribution, re-sale or use in derivative works. (C)

Accepted version downloaded from: http://eprints.soas.ac.uk/23607/

but they did negotiate their understanding of the law, sovereignty, subjecthood and citizenship.

From the Ottoman government's point of view, law had to be negotiated differently with the slave holding and enslaved refugees also. The Ottoman Empire, like all vast land empires, was accustomed to rule its diverse populations by coopting its elites, thus the imperial law primarily concerned itself, as Jane Burbank has argued for the Russian Empire, by the "rights and obligations of the local elites.",52 As Grattan Geary, the editor of Times of India put it in 1878, there was great benefit to the Ottoman government in recognizing "the authority of the Circassian chiefs over their followers," for they could, according to Geary, "keep their people in some sort of order if the government would empower them to do so:"

As it is, the law is too feeble a restraint, and the patriarchal rule of the chiefs being set aside the wild Circassian does whatever he pleases. His great physical strength and his perfect mastery over his weapons, of which he always carries a varied assortment, make him the most formidable of all the robbers in these parts. My experience was confined to those what had been taken into the Government service, and I found them to be very far the best in escort duty that I had on the whole journey. They were obliging, hearty, good-humored fellows never afraid of exertion or exposure and never inventing ingenious fictions as an excuse for coming to a premature halt. There is fine material in these Circassian settlers who have so unenviable reputation. Possibly in the reorganization of Asiatic Turkey, which cannot now be long delayed, they will be turned to good account. ${ }^{53}$

\footnotetext{
${ }^{52}$ Jane Burbank, "An Imperial Rights Regime: Law and Citizenship in the Russian Empire" Kritika: Explorations in Russian and Eurasian History, Vol. 7, No. 3 (Summer 2006), 401.

${ }^{53}$ Grattan Geary, The Times, Letters to the Editor, July 25, 1878 , 4.
} 
This article will be published in a revised form in Comparative Studies in Society and History published by Cambridge University Press https://www.cambridge.org/core/journals/comparative-studies-in-society-andhistory/all-issues This version is free to view and download for private research and study only. Not for redistribution, re-sale or use in derivative works. (C)

Accepted version downloaded from: http://eprints.soas.ac.uk/23607/

On the one hand, the Ottoman government had a lot at stake in empowering the slaveholding Caucasian elites, to be able to implement and enforce the law which otherwise would be "too feeble" to have any use at all. ${ }^{54}$ On the other, however, endorsing the "kanun-i kadim" in perpetuating slavery, undermined the very law the Ottoman state wanted to implement. Scholars of Ottoman history have pointed out this dilemma, in which the Ottoman government was caught between its old habits of rule and the new political and legal order it aspired to build. ${ }^{55}$ Most recently, Janet Klein's study of the Hamidian era efforts to include the Kurdish region "into the Ottoman fold," and the government's extensive use and abuse of the local power networks (as much as the regional conflicts) offers a good example of this dilemma. However, Klein's (and others') studies rarely go beyond the interactions between the Ottoman government and local power holders. Accordingly, law as the tracing paper of power appears to be negotiated only between these bodies whereas other, less privileged groups also took part in these negotiations whenever they could. This was especially and transparently so in the case of post-Caucasian expulsion slavery in the Ottoman Empire. The following section looks

\footnotetext{
${ }^{54}$ It is known that the Ottoman government already favored Circassian elites in specific occasions. See, for instance, the petition by Şahin Giray Bey of Zodoh tribe, in which he asked to be granted a military rank equivalent to that he had with Russian state before he departed for the Ottoman Empire, a request again deemed appropriate by the Ministry of War. BOA, A.MKT.MHM, 177/29, 1276.B.21 (13 February 1860). Similarly, Kasbolat Bey (the chieftain of the Alt1kesek tribe) petitioned to the office of the Grand Vizier and asked for an "appropriate" amount of salary, and in case that it is unattainable, an administrative position at a government institution, a request deemed appropriate by the Muhacirin Komisyonu, BOA, MVL 434/79, 1280.SS.03 (13 January 1864). For an elaborate discussion on the Ottoman policies of coopting the Caucasian and Crimean elites, see Cuthell, "The Muhacirin Komisyonu," 130-139. Cuthell argues that both the Muhacirin Komisyonu and the Ottoman government it represented "recognized and promoted continuity in the social structure common to both Crimean and Ottoman societies," 133.

${ }^{55}$ For a discussion on this particular point, see Ussama Makdisi, The Culture of Sectarianism: Community, History, and Violence in Nineteenth-century Ottoman Lebanon (Berkeley: University of California Press, 2000), introduction.
} 
This article will be published in a revised form in Comparative Studies in Society and History published by Cambridge University Press https://www.cambridge.org/core/journals/comparative-studies-in-society-andhistory/all-issues This version is free to view and download for private research and study only. Not for redistribution, re-sale or use in derivative works. ( $)$

Accepted version downloaded from: http://eprints.soas.ac.uk/23607/

into how slaves took part in these negotiations at a time when the legitimacy of slavery was highly contested and the world was increasingly more connected in ways subjecthood and citizenship, as well as the notion of justice and equality that it was hypothetically contingent upon, were understood.

\section{Freedom Suits}

"The universe of right and wrong is territorialized by a grid of laws," Michael Taussig wrote, "and each law is numbered." Those numbers, however, never quite fit reality, "neither the reality of the human condition nor the reality of the subtle distinctions necessary to law." ${ }^{56}$ The Caucasian enslaved refugees' flight from their owners, incidents of assault or other criminal acts hastily brought them into the Ottoman "legal fold," where the distinctions between their status as abd-ı hür and abd-ı memluk had collapsed and both their relationship with their owners and their social status were defined anew. Enlaved refugees' formal pleas to freedom, which began shortly after their arrival in the Ottoman domains, came precisely at this juncture and embodied an effort, however naive it may seem, to use the very same grid to thwart control of their owners over them on the one hand and to claim full membership to Ottoman society on the other. When doing so, they not only detached themselves from the Caucasian customary law and question the legitimacy of the sharì'a law but also put the old mode of Ottoman rule, defined particularly by corporate privileges, in competition with the new one,

\footnotetext{
${ }^{56}$ Michael Taussig, Law in a Lawless Land: Diary of a Limpieza in Colombia (Chicago: The University of Chicago Press, 2005), 16.
} 
This article will be published in a revised form in Comparative Studies in Society and History published by Cambridge University Press https://www.cambridge.org/core/journals/comparative-studies-in-society-andhistory/all-issues This version is free to view and download for private research and study only. Not for redistribution, re-sale or use in derivative works. ( $)$

Accepted version downloaded from: http://eprints.soas.ac.uk/23607/

characterized by the fiction of equality before the law. Thus, the disputes between the enslaved and slaveholding Caucasian, their usage of the same language of justice, yet with different meanings ascribed to it, were more than issues of ownership.

A foreign or transplanted law that enforced these descriptions of ownership was not the whole of it either. As Suraiya Faroqhi puts it, "the process of [slaves'] induction to Ottoman society was not simply a matter between slave owners and slaves," and the "state intervention went beyond simple tax collection and prevention of abuses." "Acting in the name of religious law," Faroqhi argues, "the state also attempted to enforce general urban [or provincial] order, including the hierarchy between men and women, Muslims and non-Muslims. ${ }^{, 58}$ Here we see that this involvement goes deeper than "acting in the name of religious law" or simply effecting the hierarchies in relation to what Madeline Zilfi called "the twin pillars of elite "othering," that is of women and non-Muslims, ${ }^{59}$ but all (and needless to say, shifting) subordinate groups.

The Ottoman state mapped its subjects and citizens primarily in accordance with the level of their subordination, and upheld the mechanisms that produced them. The enslaved Caucasian refugees' claims to freedom, which meant in actuality no more than full ownership of their lands, ploughs, ox and daughters at that point, were significant attempts to dismantle these mechanisms, one that was supported, at least in theory, by a

\footnotetext{
${ }^{57}$ Suraiya Faroqhi, "Quis Custodiet Custodes? Controlling Slave Identities and Slave Traders in Seventeenth and Eighteenth-century Istanbul," in Stories of Ottoman Men and Women: Establishing Status, Establishing Control (Istanbul: Eren Yayınc1l1k, 2002), 252.

${ }^{58}$ Faroqhi, "Quis Custodiet Custodes?," 252. This point constitutes the core argument of Madeline Zilfi's Women and Slavery in the Late Ottoman Empire: The Design of Difference (Cambridge: Cambridge University Press, 2010).

${ }^{59}$ Zilfi, Women and Slavery in the Late Ottoman Empire, 87.
} 
This article will be published in a revised form in Comparative Studies in Society and History published by Cambridge University Press https://www.cambridge.org/core/journals/comparative-studies-in-society-andhistory/all-issues This version is free to view and download for private research and study only. Not for redistribution, re-sale or use in derivative works. ( $)$

Accepted version downloaded from: http://eprints.soas.ac.uk/23607/

government that promised to safeguard all of its subjects' and citizens' the rights to life and property. From the beginning of the Caucasian influx at the end of the $1850 \mathrm{~s}$, enslaved refugees filed petitions or legal suits for what they believed to be their rights. These petitions put the contradictions between the transplanted/old and the existing/new legal systems in writing and elucidated what slaves made of their new "homelands," in which they were as invested as their owners.

The first mention of the enslaved refugees' organized action came in 1863. In an official report written by the Silistra council to the office of the Grand Vizier, it was noted that an ongoing dispute among Caucasian refugees on the matter of slavery had been partially resolved when the slave owners and their slaves came to an agreement to travel to Istanbul with the purpose of mutually appealing to a judge or court hearing (terafu') with the Supreme Council, but the latter reportedly changed their mind for no apparent reason. ${ }^{60}$ Upon this, the owner of the mentioned slaves Kobzik Zavir, together with other notables and elders (a total of thirty individuals), applied to the provincial court to file an official complaint about the "inappropriate" behavior of his slaves. Following the slave owners' appeal, and in compliance with the local officials' suggestion that "one or two of the slaves with trustable judgment" should also be heard, a slave named Abrek was summoned to the provincial court of Silistre and stated (on behalf of other slaves in his village) that they could not and would not travel to Istanbul for the trial, as they were not slaves but free like other freeborn people. Thus, Abrek maintained, the plaintiffs had no right to claim ownership over them and even less to

${ }^{60}$ BOA, MVL 964/64, 1280.M.18 (5 July 1863). 
This article will be published in a revised form in Comparative Studies in Society and History published by Cambridge University Press https://www.cambridge.org/core/journals/comparative-studies-in-society-andhistory/all-issues This version is free to view and download for private research and study only. Not for redistribution, re-sale or use in derivative works. (C)

Accepted version downloaded from: http://eprints.soas.ac.uk/23607/

force them to go to trial (possibly to set the terms of bondage at this point, like the use of their agricultural land and equipment, sale, and resale of their family members).

With rhetorical mastery, Abrek told the council members that he and his enslaved colleagues migrated from their native lands in the Caucasus to the Ottoman domains with the hopes and desires of ridding themselves of Russian aggression and becoming farmers, worthy of service to the Ottoman sovereign. "Now, since all of us are slaves and subjects of our Sultan," he contended, "neither he, nor God would consent to our capture and enslavement." Unless they were rounded and tied up and sent to Istanbul forcefully (which was not permissible, the council report clarified), they would not allow any one of them to be taken to Istanbul. They were not to be captured forcefully, yet plain talk did not suffice either, the provincial council complained to the Supreme Council of Judicial Ordinances (Meclis-i Vâlâ-yı Ahkâm-ı Adliye), where the case file eventually ended up. Here Abrek (as one man of trustable judgment) appeared alone in the provincial court, and yet not as a plaintiff either, but representing a joint effort against the adat-ı kadime, the slave-holding elite who claimed their ownership pertaining to that law, as well the Ottoman government, who was seeking to (re)define and enforce their status as slaves for the sake of public order and security.

These claims continued in the ensuing years and became more organized and collective in nature, producing actual petitions and lengthier arguments. In the meantime, however, both the slave owners and the Ottoman state developed their own (inter)related strategies and solutions. Convinced that manumitting slaves without the consent of their owners would bring on violent opposition and more clashes, the Council of Ministers 
This article will be published in a revised form in Comparative Studies in Society and History published by Cambridge University Press https://www.cambridge.org/core/journals/comparative-studies-in-society-andhistory/all-issues This version is free to view and download for private research and study only. Not for redistribution, re-sale or use in derivative works. ( $)$

Accepted version downloaded from: http://eprints.soas.ac.uk/23607/

suggested that self-purchase (mükâtebe) would be the best solution, ${ }^{61}$ not only to appease the ongoing or future tensions but also to resolve the matter without deviating from the

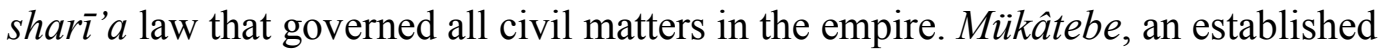
shari' $a$ procedure, allowed the slaves and slave owners to mutually determine the payment terms and to set the amount (often the equivalent of the slaves' sale price) for manumission. Upon the completion of the full payment, the slave would be given a manumission certificate and deemed free, while the owners themselves would receive a fair amount of compensation at the same time. ${ }^{62}$ One apparent problem with mükâtebe was that exceedingly impoverished enslaved refugees, who were mere sharecroppers on their owners' land, ${ }^{63}$ were not able to pay a slave's price, let alone pay for an entire family. Moreover, legally speaking, it was a voluntary procedure and could not be imposed upon slave owners, which was, as Ehud Toledano observes, a setback for the slaves: ${ }^{64}$

A mükâtebe could not be imposed on a slave owner who had not flagrantly mistreated his slave; it also gave greater leverage to the Şerî courts, before which such procedures were normally being conducted. Apparently, the government was unable to overcome the strong opposition of the Circassian slave holders, or simply preferred to avoid a direct, and undoubtedly bitter, confrontation with them. The readiness with which the Şerî courts were issuing orders supporting the position of slave owners against the claim of their slaves put the government

\footnotetext{
${ }^{61}$ Toledano, The Ottoman Slave Trade and its Suppression, 164-165.

${ }^{62}$ Ibid.

${ }^{63}$ The initial land distribution among Circassian immigrant-refugees was reportedly not based on exceptions or princely prerogatives, and was done in accordance with household divisions. But since the slave families were attached to their owners' households and the land titles were registered with the owners' names, the slaves could not legally claim ownership of the land. See BOA, ŞD 2396/18, 1289.Ra.8 (16 May 1872), 8.

${ }^{64}$ Toledano, The Ottoman Slave Trade and its Suppression, 165-166.
} 
This article will be published in a revised form in Comparative Studies in Society and History published by Cambridge University Press https://www.cambridge.org/core/journals/comparative-studies-in-society-andhistory/all-issues This version is free to view and download for private research and study only. Not for redistribution, re-sale or use in derivative works. (C)

Accepted version downloaded from: http://eprints.soas.ac.uk/23607/

in a different situation. [...] [t] he courts impeded the authorities' actions which were meant to benefit the slaves. This may be indicative of a general mood in religious circles, one which upheld the legality of slavery because it was sanctioned by Islam. The government, it should be stressed, was consistently careful in emphasizing the slavery, as distinct form of the slave trade, was not to be interfered with. The Persian Gulf ferman of 1847, the prohibition of the Circassian and Georgian slave trade in 1854, and the ferman of 1857 against the traffic in blacks come to mind in this context. It was only the institution of agricultural slavery among the Circassians that Porte was trying to dismantle, and that too - in the face of strong opposition — it did gradually, with great caution, somewhat diffidently. ${ }^{65}$

That the Ottoman government appeared sympathetic to the cause and claims of the slaves, at least more so than the sharì' $a$ courts, was not because it was inherently good-natured or benign. In fact, the Ottoman government too favored the slave owners over slaves under most circumstances, but it did so more subtly and with a different set of obligations and priorities, particularly at the international level, in comparison to the sharì' $a$ courts, which were exceedingly and purposefully local. ${ }^{66}$ First of these concerns had to do with the Ottoman government's obligation to comply or at least respond to intensifying international, particularly British, efforts towards the wholesale abolition of slavery throughout the Ottoman domains. Starting with the 1847 Persian Gulf ferman, the Ottoman government issued imperial decrees that also functioned as pacts and treaties

\footnotetext{
${ }^{65}$ Ibid., 166.

${ }^{66}$ That the courts favored slave-holders over slaves has been noted by Toledano in As if Silent and Absent, 95-96; Guy Burak has argued that the "locality" of such legal practices or posts were indicative of local power relations, Burak, The Second Formation of Islamic Law, 54. Boğaç Ergene further demonstrated that several legal and administrative ranks of these courts comprised local notables, many carrying "military and religious titles." Ergene, Local Court, Provincial Society and Justice in the Ottoman Empire: Legal Practice and Dispute Resolution in Çankırt and Kastamonu (1652-1744) (Leiden: Brill, 2003), 29.
} 
This article will be published in a revised form in Comparative Studies in Society and History published by Cambridge University Press https://www.cambridge.org/core/journals/comparative-studies-in-society-andhistory/all-issues This version is free to view and download for private research and study only. Not for redistribution, re-sale or use in derivative works. (C)

Accepted version downloaded from: http://eprints.soas.ac.uk/23607/

between the Ottoman and other governments including Great Britain, Austria, Prussia, Russia, and France, which gave the latter the right of search and seizure, as necessary. ${ }^{67}$ The short lived ban of trade in Caucasian slaves necessitated by the Crimean War in 1854, and the more encompassing and carefully enforced prohibition of trade in African slaves in 1857 both had binding effects that brought a close monitoring of the Ottoman sea and land routes by the British consular offices, commercial agents, as well as naval forces in the Mediterranean. Unlike the issue of trade in African slaves, the Ottoman government managed to dodge the British demands on the abolition of Caucasian slavery to a great extent, but this did not mean that it was entirely immune to foreign control, which continued to push for measures against in the following decades. ${ }^{68}$

More importantly, perhaps, in the aftermath of the 1839 and 1856 protoconstitutions, a period that Thomas C. Holt described as "a particular moment in the [global] history of classical liberalism," the Ottoman government had domestic obligations, at least aspirations of providing for all its citizens a degree of equality before the law. ${ }^{69}$ Developed as "a strand of British and French political thought" that appeared

\footnotetext{
${ }^{67}$ For an excellent analysis of how Ottoman slavery was put into use to enforce imperial hierarchies in the nineteenth century Mediterranean, see Alison Frank, "The Children of the Desert and the Laws of the Sea: Austria, Great Britain, the Ottoman Empire, and the Mediterranean Slave Trade in the Nineteenth Century," The American Historical Review vol.117, no. 2 (2012), 414-415; The British pressures to abolish Ottoman slavery, which Eve Troutt Powell called "invasive abolitionism," has been extensively discussed by the historians of Ottoman and Middle Eastern slavery. See Eve Troutt Powell, A Different Shades of Colonialism: Egypt, Great Britain, and the Mastery of the Sudan (Berkeley: University of California Press, 2003), 136-141; Erdem, Slavery in the Ottoman Empire and its Demise, 67-93; Toledano, Slavery and Abolition, 112-134.

${ }^{68}$ Erdem, Slavery in the Ottoman Empire and its Demise, 113-114; Toledano, Slavery and Abolition, 113.

${ }^{69}$ Thomas C. Holt, "The Essence of the Contract: The Articulation of Race, Gender, and Political Economy in British Emancipation Policy, 1838-1866" in Beyond Slavery, 37-38.
} 
This article will be published in a revised form in Comparative Studies in Society and History published by Cambridge University Press https://www.cambridge.org/core/journals/comparative-studies-in-society-andhistory/all-issues This version is free to view and download for private research and study only. Not for redistribution, re-sale or use in derivative works. (C)

Accepted version downloaded from: http://eprints.soas.ac.uk/23607/

committed to such values as "equal human dignity, freedom, the rule of law, and

accountable, representative government," and held at first a promise, as Jennifer Pitts has argued, "of a critical approach to European expansion," liberalism became by 1830s an ideology that was put into use to support imperial projects. ${ }^{70}$ It has been "plausibly implicated," as Andrew Sartori has pointed out, "in the conceptualization, institutionalization and legitimization of hierarchical practices of subordination on the basis of race, gender and other categories of difference $[\ldots]$ in the constitution of new regimes of colonial governmentality; in the annihilationist violence against the nomadic aboriginal populations of the settler colonies; and in a vast assault on indigenous epistemological and ethical norms." ${ }^{, 71}$ In that, by the time the Ottoman government embraced the globally spread liberal principles of freedom and equality before the law, those had already become the formulae "for exercising power."72

\footnotetext{
${ }^{70}$ Jennifer Pitts, A Turn to Empire: The Rise of Imperial Liberalism in Britain and France (Princeton: Princeton University Press, 2005), 2-3. Also see Pitts's article "Liberalism and Empire in a Nineteenth-Century Algerian Mirror,” Modern Intellectual History, vol.6, issue 2 (August 2009).

${ }^{71}$ Andrew Sartori, Liberalism in Empire: An Alternative History (Berkeley: University of California Press, 2014), 4.

${ }^{72}$ Patrick Joyce, The Rule of Freedom: Liberalism and the Modern City (London: Verso, 2003), $1-2$. There is a large literature that focuses on the ways in which liberalism encountered the world. In addition to the studies by Thomas C. Holt, Jennifer Pitts and Andrew Sartori cited above, see, Thomas R. Metcalf, Ideologies of the Raj (Cambridge: Cambridge University Press, 1995); Uday S. Mehta, Liberalism and Empire: A Study in Nineteenth-Century British Liberal Thought (Chicago: University of Chicago Press, 1999); C.A. Bayly, Recovering Liberties: Indian Thought in the Age of Liberalism and Empire (Cambridge: Cambridge University Press, 2012). Although such Tanzimat era intellectuals as Şinasi and Namık Kemal, two prominent figures in the Young Ottoman movement that culminated in the promulgation of the Constitution proper in 1876 , are known to be well immersed in the liberal thought, there is no systematic study, to my knowledge, on liberalism as a mode of rule in the Ottoman Empire. The existing literature, moreover, continues to divide the global nineteenth century into binary liberal and illiberal polities, that of the Muslim East and the Christian West, blaming the "missionaries of liberalism" trying to "convert Muslims and Islam to Western liberalism and its value system as the only just and sane system to which the entire planet must be converted." Joseph A. Massad, Islam in
} 
This article will be published in a revised form in Comparative Studies in Society and History published by Cambridge University Press https://www.cambridge.org/core/journals/comparative-studies-in-society-andhistory/all-issues This version is free to view and download for private research and study only. Not for redistribution, re-sale or use in derivative works. ( $)$

Accepted version downloaded from: http://eprints.soas.ac.uk/23607/

Whether the slave petitions and claims by the Caucasian enslaved refugees were touched by these international developments and domestic aspirations is difficult to say. In most cases, they did not refer to the general ban of 1857 as one would expect them to do, nor did they allude to then recent abolition of serfdom in Russia, or the Emancipation Proclamation in America. One related note, however, written by the office of the Grand Vizier to the Muhacirin Komisyonu, pointed at the problem of the Ottoman governments' ambivalent position vis-à-vis Caucasian vs. African slavery and the possible discontentment it would cause among Caucasian slaves. While both the new importation and the sale and purchase of existing African slaves had already been banned throughout the empire and were subjected to an international law, the note stated, the Caucasian ones were made exceptions and their previous statuses (determined by the adat-ı kadime) were upheld. The importation of slaves from refugee settlements, and their sale ("openly, here and there" the note underlined) continued without much hindrance. ${ }^{73}$

This ambivalence and discrepancy would become one of the central arguments for the reformers (most notably the Ministry of Justice and Caucasian intellectual organizations) demanding the wholesale abolition of slavery several decades later. The semi-official proclamation announced by the Ministry of Justice in late 1908 clearly stated the sale and purchase of Caucasian slaves was prohibited, just as the trade in African slaves had been for a long time. ${ }^{74}$ On a related note, the slave holders who

Liberalism (Chicago: The University of Chicago Press, 2015), 3. These neat divisions obscure the "internal inconsistencies" of liberalism on the one hand while disregarding other, more complex, challenges to it on the other.

${ }^{73}$ BOA, A.MKT.MVL 140/4, B.23.1278 (24 January 1862).

${ }^{74}$ See İkdam, 17 Teşrinisani 1324 for an example of the announcement note. 
This article will be published in a revised form in Comparative Studies in Society and History published by Cambridge University Press https://www.cambridge.org/core/journals/comparative-studies-in-society-andhistory/all-issues This version is free to view and download for private research and study only. Not for redistribution, re-sale or use in derivative works. (C)

Accepted version downloaded from: http://eprints.soas.ac.uk/23607/

claimed that their ownership of their slaves had a sharī'a basis (supported by numerous ayat and hadith, as they clarified) found the abolition of trade in African slaves deployed against them as a claim-making strategy, both by the slaves themselves and the reformers that demanded general abolition. As one reformer would articulate in 1909, even if the ownership of Caucasian slaves was a sharī'a principle or right, had the African slaves not already been exempted from the jurisdiction of sharī'a law ${ }^{75}$ Similarly, the Minister of Justice made an argument against slavery by pointing out that "slavery pertaining to the white race was already abolished by the Russian government in territories under their control" when the Caucasians emigrated to the Ottoman lands; a fact that rendered, according to the minister, the claims to slave ownership by Caucasia notables unfounded. $^{76}$

Neither Azizian nor Hamidian-era Ottomans openly celebrated "freedom, equality, justice," as their counterparts would do in the post-1908 constitutional revolution, but the idea that slavery was essentially incompatible with both the 1839 and 1856 constitutions was in the making as early as the1860s, and Caucasian slaves were instrumental in bringing that debate to the foreground. Save for "a few individuals who expressed disapproval of enslavement," however, they were alone in doing so. ${ }^{77}$ As Ehud Toledano has rightly noted, the abolition of trade in African slaves in 1857 "was not obtained as a result of successful persuasion [...] but a sustained pressure through

\footnotetext{
${ }^{75}$ BOA, ŞD 2786/29, 1327.N.14 (29 September 1909), 66. Karamursel, "“"The Uncertainties of Freedom," 146.

${ }^{76}$ BOA, ŞD 2786/29, 1327.N.14 (29 September 1909), 66.

${ }^{77}$ Ehud R. Toledano, "Abolition and Anti-slavery in the Ottoman Empire: A Case to Answer?," in A Global History of Anti-Slavery Politics in the Nineteenth Century, eds., William Mulligan and Maurice Bric (London: Palgrave Macmillan, 2013), 120.
} 
This article will be published in a revised form in Comparative Studies in Society and History published by Cambridge University Press https://www.cambridge.org/core/journals/comparative-studies-in-society-andhistory/all-issues This version is free to view and download for private research and study only. Not for redistribution, re-sale or use in derivative works. ( $)$

Accepted version downloaded from: http://eprints.soas.ac.uk/23607/

diplomatic channels." ${ }^{, 78}$ As the anti-slavery debate never reached a critical mass and that the Ottoman government never had to deal with public demands, Toledano maintained, the political significance of the slaves' claims to individual rights to freedom and equality before the law was never sufficiently highlighted. Even though they made use of the same universal language of "freedom" used by the abolitionists and reformers, theirs could never turn into a moral or ethical quest against the "greater evil" of slavery but remained as mere local demands. Before eventually turning into corporate claims for a "Circassian nation" towards the end of the nineteenth century, they were directed at a set of immediate problems and tangible items, such as the breaking up of their families and sale of their daughters or the appropriation of their land and animals by the their owners.

Such was the case described by a slave named Mehmed in his brief petition to the Council of State (Şura-yl Devlet) in July $1872 .{ }^{79}$ Mehmed and other slaves from the town of Silivri brought legal action against their owners five years before the petition, that is, not long after their settlement in the area. While their first attempt was hastily suppressed by local legal bodies, they succeeded in bringing the case to a court in Istanbul and had been collectively residing there because of it. While Mehmed and his colleagues were following a strictly legal path to claim their freedom, the slave owners were far from keeping within the "prescribed boundaries" of the law, refused to wait for the result of the legal procedure, and restored their violent means and tyrannized the remainder of the

\footnotetext{
${ }^{78}$ Ibid., 118.

${ }^{79}$ BOA, ŞD 2872/30, 1289.Ra.7 (15 May 1872). Branched off from the Supreme Council of Judicial Ordinances (Meclis- $i$ Vâlâ- yı Ahkâm- $\imath$ Adliye) in 1868, the Council of State was a consultative assembly, where complex legal matters that could not be resolved or referred to by law was brought to.
} 
This article will be published in a revised form in Comparative Studies in Society and History published by Cambridge University Press https://www.cambridge.org/core/journals/comparative-studies-in-society-andhistory/all-issues This version is free to view and download for private research and study only. Not for redistribution, re-sale or use in derivative works. ( $)$

Accepted version downloaded from: http://eprints.soas.ac.uk/23607/

slave population in Silivri, with the purpose of obtaining half of the grain that was recently harvested.

These specific instances of violence and abuse on the slave owners' side demanded a specific set of responses. Moreover, at the core of the enslaved refugees' claim to freedom was the assertion of their difference from the remainder of the slave population, particularly those employed in domestic settings in the Ottoman center.

Another, lengthier, petition filed by Haydar, Osman, and Zoş to the Council of State in 1872 provides a more detailed depiction of this particular point. Acting as representatives (vekil) on behalf of all those "who [were] called slaves among the Circassian refugees that settled in Rumelia and Anatolia," Haydar, Osman, and Zoş had been carrying out legal action of a similar nature for the past several years. "It must be our poor command of [Turkish] and the errors we made in expressing our intention thereof," they wrote in a sarcastic tone, "that hindered and delayed the receipt of the answers and just solutions we have been demanding in the last several years. ${ }^{\prime 80}$ In their petition supplemented by a sixteen-item fact list, theirs was not a discursive "double plea of humanity and international right, ${ }^{, 81}$ but a response to actual problems, concepts, and definitions.

The first of these concepts had to do with the question of what it meant to be a citizen in relation to a sovereign power. In their native land of the "Circassian Mountain" (Çerkestan Dă̆l), the discussion went, they were not under the protection of any

\footnotetext{
${ }^{80}$ BOA, ŞD 2396/18, 1289.Ra. 8 (16 May 1872), 21.

${ }^{81}$ This expression was used by the The National Magazine in the context of two Caucasian beys, Hadji Hayden Hassan and Kustan Ogli Islam, visiting England and petitioning Foreign Secretary Earl Russel in 1863. Here I borrow it to highlight the rhetorical character of such broad claims. "Our Dominions in India," The National Magazine, January 1863, 13, 75, 97-99.
} 
This article will be published in a revised form in Comparative Studies in Society and History published by Cambridge University Press https://www.cambridge.org/core/journals/comparative-studies-in-society-andhistory/all-issues This version is free to view and download for private research and study only. Not for redistribution, re-sale or use in derivative works. ( $)$

Accepted version downloaded from: http://eprints.soas.ac.uk/23607/

monarch, thus the stability and the order they needed (simple and vulnerable peasants as they were, they added) came from what they called "a few able swordsmen and those who had the "will to war." 82 Their present status as slaves originated within a specific context when their ancestors sought the protection of the local power holders and that their status in time was relegated from peasants to slaves. Even when not the case, however, the root of the problem that afflicted them now had to do with the terminology rather than anything else: the word slave (köle) was understood only as those employed in domestic settings and sold at will (which in fact was incompatible with the adat-l kadime, they clarified), but what they really ought to be called was peasants (reaya).

The petition clarified that this wrong usage of the word slave was devised by the slaveholding Caucasian elites themselves, who were accustomed to act as the sovereign in their native lands, which now was challenged by the Ottoman state. ${ }^{83}$ Only by holding on to their slaves (and defining them as such, before all), the petitioners argued, the Caucasian elites could hold on to or assert their princely qualities that they believed they had and guarantee their gains through payments they extorted from their slaves or simply by selling them. ${ }^{84}$ This situation of being at the service of both the Ottoman state and the Caucasian princes, which meant paying two separate taxes, was not only beyond the limit of their means but also impaired the authority of the Ottoman state itself. Moreover, their legal status as slaves exempted them from the military draft. While all other immigrants

\footnotetext{
${ }^{82}$ BOA, ŞD 2396/18, 1289.Ra.8 (16 May 1872), 19/1.

${ }^{83}$ Ibid., $19 / 2$.

${ }^{84}$ Ibid., 21.
} 
This article will be published in a revised form in Comparative Studies in Society and History published by Cambridge University Press https://www.cambridge.org/core/journals/comparative-studies-in-society-andhistory/all-issues This version is free to view and download for private research and study only. Not for redistribution, re-sale or use in derivative works. (C)

Accepted version downloaded from: http://eprints.soas.ac.uk/23607/

became eligible for the draft seven years after their arrival in the country, they were held back by their owners, which caused another harm to the Ottoman state.

In a long official report, the Council of State agreed upon the rightfulness of Haydar, Osman, and Zoş’s central claim. Like all other classes and groups of subjects,

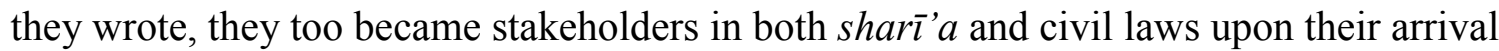
to the Ottoman domains, which should have invalidated their status as slaves. ${ }^{85}$ But their enslaved status was due to an old and widespread custom (itiyad) among the Caucasians, and the existence of it was acknowledged even by the slaves themselves. ${ }^{86}$ Thus, the Council concluded, this long-established and acknowledged category could not retrospectively or automatically be undone by the simple fact that they migrated to another land. Ignoring, for the most part, the enslaved refugees' elaborate arguments on the meanings of citizenship, the Ottoman government in general and the Council of State in particular concerned themselves with finding a practical solution to the problem. Once again, they proposed the promotion of mükâtebe as a safe, just, and in effect, the only option towards a wholesale abolition of slavery in the Ottoman domains.

Fearing that the conflicts and fights between the two parties would get more violent and spread to the rest of the society and turn into a general turmoil, the Council advised against any coercive measures against slaves or slave owners and highlighted the importance of bringing limitations to both sides. Accordingly, slave owners were banned from breaking up families and the age limitations debated earlier were reiterated. In short,

\footnotetext{
${ }^{85}$ Ibid., 9.

${ }^{86}$ Both Ehud Toledano and Hakan Erdem mention about a similar decision by Council of Ministers in 1867. Toledano, Slavery and Abolition, 96-97; Erdem, Slavery in the Ottoman Empire and its Demise, 118.
} 
This article will be published in a revised form in Comparative Studies in Society and History published by Cambridge University Press https://www.cambridge.org/core/journals/comparative-studies-in-society-andhistory/all-issues This version is free to view and download for private research and study only. Not for redistribution, re-sale or use in derivative works. (C)

Accepted version downloaded from: http://eprints.soas.ac.uk/23607/

the Ottoman government opted for regulating and ameliorating the conditions of slavery, but eschewed an apparent intervention to achieve a wholesale abolition, even though it was aware of its undermining effects, which was discussed, "one by one, item by item" by the enslaved refugees in their claims to freedom. In fact, even the military draft was partially left to the slave owners' consent and will. The Council stated that those who were already in the process of mükâtebe could enter into army service, as a way of paying the self-purchase fee, but only with permission obtained from their owners. ${ }^{87}$ In that, the Ottoman government undermined its power as the "holder of the sovereign decision," by tying it to the consent of another authority. ${ }^{88}$ All in all, the Ottoman government failed to bring about an effective solution, and instead continued with half measures, that benefited in most cases only the slave owners. ${ }^{89}$ In other words, its justice betrayed the slaves who had the most faith in it. We know that these half measures as limitations and regulations were hardly enforced in the following decades also, as the Caucasian settlements continued to supply the urban and provincial elite households with women and young girls as slaves. $^{90}$

\footnotetext{
${ }^{87}$ Erdem, Slavery in the Ottoman Empire and its Demise, 16.

${ }^{88}$ Giorgio Agamben, State of Exception (Chicago: The University of Chicago Press, 2005), 20.

${ }^{89}$ Erdem, Slavery in the Ottoman Empire and its Demise, 120.

${ }^{90}$ It is important to note that even though women were central to the claims to freedom in many slave petitions, the experience of slavery and freedom for women remained different from that of male slaves. Women and children, whose flow especially towards Istanbul did not cease for at least another four decades, developed other sorts of relationships both with their owners and slavery as a practice. For a gender-focused discussion of emancipation, see Ceyda Karamursel, "“'In the Age of Freedom, In the Name of Justice": Slaves, Slaveholders, and the State in the Late Ottoman Empire And Early Turkish Republic, 1857-1933," (PhD Dissertation, University of Pennsylvania, 2015), chapter 3 ("Slaver-Mistresses, Matchmakers, and Destitute Women" and Karamursel, "Uncertainties of Freedom." For a note on the vulnaribilities of Caucasian women who managed to obtain their freedom in the aftermath of the Caucasian expulsion, see BOA, SSD 2395/3, 1288.B.15 (30 September 1871).
} 
This article will be published in a revised form in Comparative Studies in Society and History published by Cambridge University Press https://www.cambridge.org/core/journals/comparative-studies-in-society-andhistory/all-issues This version is free to view and download for private research and study only. Not for redistribution, re-sale or use in derivative works. ( $)$

Accepted version downloaded from: http://eprints.soas.ac.uk/23607/

In fact, even the principal purpose of the Ottoman government's appeasement strategies failed, and the clashes between the slaves and slave owners continued in the ensuing years. A year after the Council's official communication, in 1873, a note written by the office of the Grand Vizier reported on the difficulties the slaves encountered in paying the self-purchase amounts that were previously decided on. The office suggested that the fee should be paid in kind, with whatever was left from the previous year's and half of the current year's crop. ${ }^{91}$ The fee could also be paid in cash, by auctioning the crop, if the slaves preferred to do so. In almost an automated-sounding response, the Ottoman government reiterated that mükâtebe would protect and guarantee the shari' $a$ rights of both parties and help in doing away with the ongoing strife and for that reason, should be put into practice and the results be reported to the office of the Grand Vizier at once.

Just when the Grand Vizierate issued this decision, an incidence of unrest was communicated from Canik, where armed slaves and slave owners reportedly assembled in the town square. The report explicated that there too, a group of slave representatives had been to Istanbul in pursuit of legal action to undo or get rid of their slave status. While there, the slaves and the slave owners came to an agreement on the implementation of mükâtebe for the manumission of the slaves, but the latter retreated from the agreement and could not be persuaded in its implementation, even though they were given detailed explanations on the benefits of the solution. The parties were eventually calmed down through the local government's intervention, but given that the matter was

${ }^{91}$ BOA, A.MKT.MHM 461/26, 1290.C.16 (11 August 1873). 
This article will be published in a revised form in Comparative Studies in Society and History published by Cambridge University Press https://www.cambridge.org/core/journals/comparative-studies-in-society-andhistory/all-issues This version is free to view and download for private research and study only. Not for redistribution, re-sale or use in derivative works. (C)

Accepted version downloaded from: http://eprints.soas.ac.uk/23607/

left at a stalemate, it could be resumed any moment. Just as there were slave owners who refused to go into mükâtebe arrangements with their slaves, there were cases in which slaves rejected the idea of them paying for their manumission. A case from Çorlu from 1874 is told by Hakan Erdem as follows: ${ }^{92}$

According to [the British Vice-consul in Edirne], the slaves asserted their freedom first, then the masters took up arms to compel them to return to their state of slavery unless they chose to purchase their liberty. It must immediately be observed that the masters were in fact willing for a mükâtebe but the slaves wanted to be free without paying for their manumission. [...] The local government assembled troops complete with field guns and 'informed the Circassian Beys of the Porte's instructions, threaten to abandon them to military.' The Beys had little option but to consent to the terms of the government. This was a radically different situation from that envisaged by the aforementioned decisions of the Council. The slaves were to be freed 'without money payments, the owners to receive as compensation the whole of the lands they hitherto held in common with the slaves.' The slaves, on the other hand, were to be dispersed 'among Turkish villages' and to have other land parcels. [The Vice-consul] added that there were some ninety Circassian chiefs connected with the late disturbances in the Edirne prisons.

Judging by the sizeable number of slaves petitioning with similar claims in the aftermath of the 1908 revolution, we know that mükâtebe, which the Ottoman government insisted upon, was far from bringing on a general or wholesale abolitionary solution. As already discussed above, it was after all a voluntary agreement, one that was at the slave owners' discretion. In that, it even failed to provide the means to secure public order that the Ottoman government valued most. Consequently, the course of the

\footnotetext{
${ }^{92}$ Erdem, Slavery in the Ottoman Empire and its Demise, 119.
} 
This article will be published in a revised form in Comparative Studies in Society and History published by Cambridge University Press https://www.cambridge.org/core/journals/comparative-studies-in-society-andhistory/all-issues This version is free to view and download for private research and study only. Not for redistribution, re-sale or use in derivative works. ( $)$

Accepted version downloaded from: http://eprints.soas.ac.uk/23607/

Caucasian expulsion as an elongated period of crisis created an overabundance of law

that had to redefine its limits almost with each individual case, which gave Ottoman

emancipation a highly arbitrary character, an arbitrariness that continued to bend

categorical limits until the dissolution of the empire, creating as much silence as

discussion on who was entitled to freedom and equality before the law and who was not, along the way. 